\title{
2-1 脳卒中後遺症患者の下腿サーモグラム
}

一第 4 報一 局所温浴後の皮膚温の経時的変動ならび

にそのパターンの変化について

対象ならびに方法：脳血栓22名, 脳塞栓 3 名, 脳出血14名の計39名の片麻瘦患者にインフラア イを用いてサーモグラフィ（サーモ）を行なっ た。第 1 回目のサーモの時点は，脳卒中発作後 1 力月ないし 3 年 8 力月であった。

患者の両下腿を $20^{\circ} \mathrm{C}$ 前後の室内に約 20 分間 露出した後に，まずサーモを行ない，次にその 後ただちに雨下腿に $40^{\circ} \mathrm{C}, 5$ 分間の温浴を行 ない，温浴終了後は，約 1 時間にわたって，経 時的に約12回のサーモを行なった.さらに, こ れらの39名のうち, 脳血栓 7 名, 脳出血 8 名, 脳塞栓 2 名の計 17 名について, その後 1 力月か ら11九月の間に，再び同様に局所温浴をして， 2 回目のサーモを行ない，このサーモと第 1 回 目のサーモとの間でそのパターンを比較した. なお第 1 回目と第 2 回目のサーモの間も，この 17名はリハビリテーション訓練をうけていた。 結果：温浴後の皮虐温の経時的変動は，第 3 報

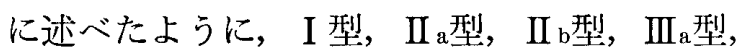
II型の 5 型に分けることができだ．Ｉ型は， 脳血栓 5 名, 脳出血 2 名, 脳塞栓 2 名の計 9 名 であり， II $\mathrm{a}$ 型は，脳出血 1 名， II $\mathrm{b}$ 型は，脳血 栓 3 名と脳出血 2 名の計 5 名であり， III 型は, 脳血栓11名, 脳出血 8 名, 脳塞栓 1 名の計 20 名 であり，III 型は，脳血栓 3 名と脳出血 1 名の 計 4 名でった.

2 回のサーモを行なった17名のうちで，パタ ーンの変化がみられたものは, 脳血栓 7 名中の
弘前大学医学部大池内科

黎明郷リハビリテーション病院

弘前大学保健管理センター

$\begin{array}{lll}\text { 柳 一 雄 } & \text { 大池弥三郎 } & \text { 小野寺庚午 } \\ \text { 松井哲郎 } & \text { 菅原英保 } & \text { 玉田友一 } \\ \text { 目時弘文 } & \text { 我那龩安彦 } & \text { 工藤良三 } \\ \text { 竹川弘美 } & \text { 山田幸夫 } & \text { 伊藤久夫 }\end{array}$

3 名, 脳出血 8 名中の 4 名, 脳塞栓 2 名中の 1 名の計 8 名であり, 残りの 9 名ではパターンの

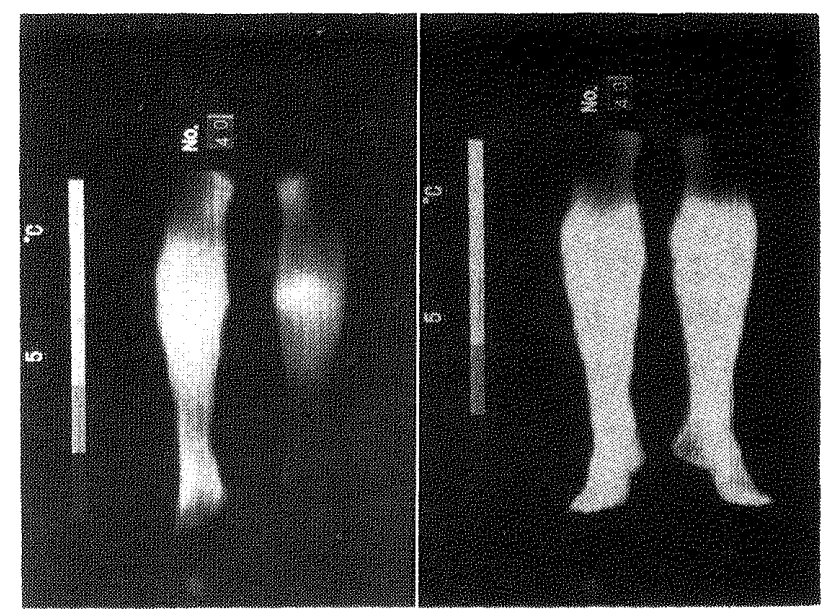

温浴前

温浴終了後 2 分

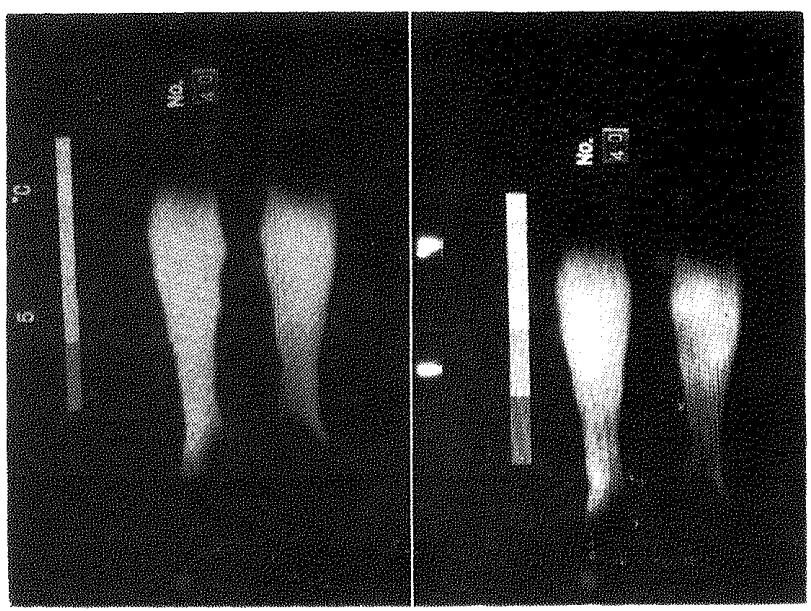

温浴終了後10分

温淠終了後 20 分

写真 1 譄塞栓, 左片麻疸, 37歳女, 両下腿正面 サーモグラム。基準温度 $29^{\circ} \mathrm{C}$ 温度差 $5^{\circ} \mathrm{C}$ 一 I 型一 


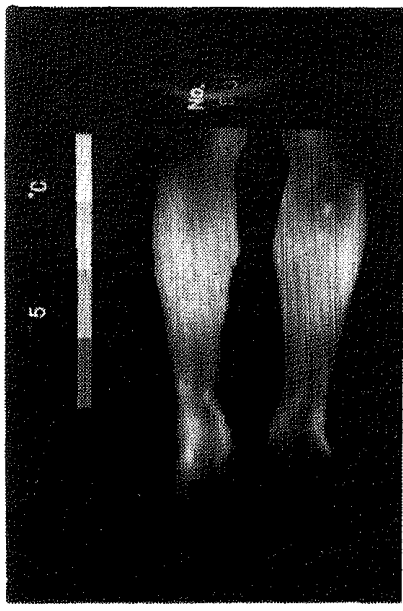

温 浴 前

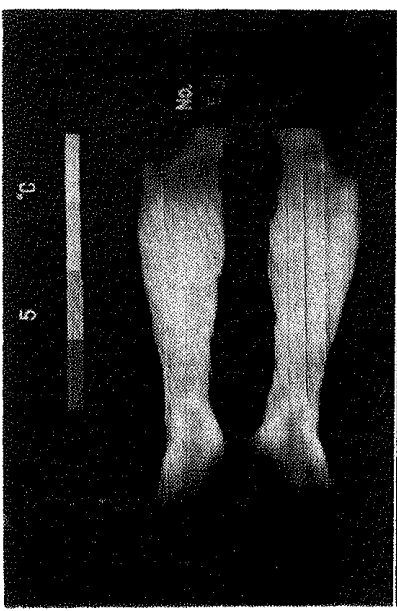

温浴終了後20分

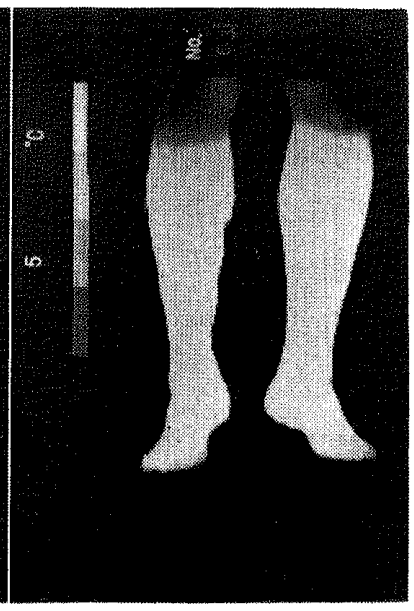

温浴終了後 3 分

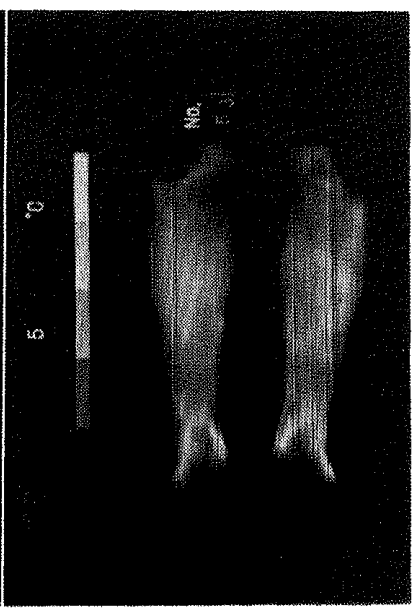

温浴終了後45分
写真 2 脳塞拴, 左片麻㾝, 37歳女, 両下腿正面 サーモグラム. 基準温度 $29^{\circ} \mathrm{C}$ 温度差 $5^{\circ} \mathrm{C}$ --III a 型一
変化はみられなかった。

脳卒中発作から第 1 回目のサーモ撮影までの 期間が約 7 カ月目までの 9 名では，パターン変 化のみられたものは 6 名であったが， 8 力以 上を経過した 8 名では 2 名に過ぎなかった。す なわち発作後比較的短期間の例ではパターンの 変動する例の多いことがわかる.

ここに揭げる症例は脳塞栓・左片麻痺・37歳 女性であるが，その両下腿正面サーモのうち， 写真 1 は, 発作後 1 力月のもので I 型である. 写真 2 は, さらに 1 力月後のものでIII 型に変 化している.

考寀：これらのパターンの発現機序およびパ ターンの変化は，血管運動神経ならびにその反 応性等にも関係があるのではないかと思われる しかし，その他に脳傷害の部位，その程度，動 脈の硬化度等も考慮しなければならないだろ 5 .

結語 : 脳卒中後遗症患者の両下腿温浴後の皮 膚温の経時的変動のパターンは, 脳卒中発作か ら約 7 力目までの間では流動的であるが， そ れ以降の時点では固定する傾问にある.

\section{参考文献}

1) 柳一雄・他：脳卒中後遺症患者のサーモグラム, 医科器械学雑誌, 42, 6161974 .

\section{$2-2$ 医用サーモカメラの眼科的応用}

名古屋保健衛生大学眼科学教室

馬嶋 慶 直 平光忠 久

名古屋保健衛生大学放射線科

沢田武司
臨床上，眼に対して温度変化を与えることに より治療効果を期待する場合がかなりあり，ま た患者の自覚症状としても熱冷感に関するもの が比較的多くみられる.ところがこれまで眼球 およびその周辺部の温度の状態およびその恋動 に関する研究はあまりなされていない。

今回，われわれは医用サーモカメラを用いて
眼科分野での温度動態の研究を行ない，眼球お よび周辺部の様態をより多面的に把握しようと した。使用したサーモカメラはキャノン製，C T-4A型のものである。

正常人の温度分布パターンでは，眼球はその 周囲皮膚部よりも低温を示し，更に角膜中央部 は，角膜周囲部に比べて $0.6 \sim 0.8^{\circ} \mathrm{C}$ ほど低温 